\title{
Influence of the limitation of intraoperative fluids volume on haemodynamics and stress response in children undergoing orthopaedic surgery.
}

I. Kyselova, O. German, A. Biliaiev

Shupyk National Medical Academy of Postgraduate Education - Kyiv (Ukraine) COPENHAgEN 02-04 JUNE

\section{BACKGROUND AND GOAL OF STUDY:}

Avoiding of perioperative fluid overload is a part of fast-track surgery and is well studied in adults [1]. However, the limitation of intraoperative fluid therapy remains unexplored in children. The need for fluids in children differs depending on the age, and exceeds those in adults. The aim of our study is to estimate influence of the restrictive fluid regimen on haemodynamics and stress response in children undergoing orthopaedic surgery.

\section{MATERIALS AND METHODS:}

After receiving the ethic committee approval and parent's consent we conducted prospective study, which included 60 patients, aged 2-16 y.o. Patients had ASA status I and II and underwent 1-3 hours orthopaedic surgery. Children received oral carbohydrate drink (25\% maltodextrin) 2 hours prior the surgery in accordance with the principles of the ERAS program. Group $1 \quad(n=30)$ received the standard regimen of fluid therapy. Group $2(n=30)$ was limited in fluids. We evaluated intraoperatively changes of haemodynamic parameters, $\mathrm{Hb}$ and $\mathrm{Ht}$, urine output, blood glucose, insulin and the insulin resistance index HOMA-IR (homeostatic model assessment). Mean data were compared with Mann-Whitney U-test.

\begin{tabular}{|c|c|c|c|}
\hline & $\begin{array}{c}\text { Group 1 } \\
\mathrm{n}=30, \\
\mathrm{M}(\mathrm{SD})\end{array}$ & $\begin{array}{c}\text { Group 2 } \\
\mathrm{n}=30, \\
\mathrm{M}(\mathrm{SD})\end{array}$ & P value \\
\hline $\begin{array}{c}\text { Duration of surgery, min } \\
\text { Duration of anaesthesia, } \\
\mathrm{min}\end{array}$ & $109,7(51,6)$ & $135,5(80,7)$ & 0,76 \\
\hline $\begin{array}{c}\text { Blood loss, ml/kg } \\
\text { Maltodextrin per os, } \\
\mathrm{ml} / \mathrm{kg}\end{array}$ & $5,6(6,3)$ & $183,5(89,7)$ & 0,15 \\
\hline $\begin{array}{c}\text { Fluid volum, ml/kg/h } \\
\text { Glucose, \% }\end{array}$ & $10,7(3,0)$ & $5,07(1,15)$ & 0,89 \\
\hline \multicolumn{2}{|c|}{$0,8(0,5)$} & $0,9(0,5)$ & 0,001 \\
\hline
\end{tabular}

References:1. Bundgaard-Nielsen M, Secher $\mathrm{NH}$, Kehlet $\mathrm{H}$.

\section{RESULTS AND DISCUSSION:}

The volume of intravenous fluids was $10,7 \pm 3,03$ $\mathrm{ml} / \mathrm{kg} / \mathrm{h}$ in group 1 and $5,07 \pm 1,15 \mathrm{ml} / \mathrm{kg} / \mathrm{h}$ in group 2. The results of the study did not reveal significant changes in haemodynamic parameters such as blood pressure, heart rate, systolic output, except for a decrease in urine output in the restrictive volume group $(1,16 \pm 0,89$ vs $0,43 \pm 0,59 \mathrm{ml} / \mathrm{kg} / \mathrm{h}$, $\mathrm{P}=0,009)$. Changes in $\mathrm{Hb}$ and $\mathrm{Ht}$ were comparable in both groups. With a slight increase of glucose in both group, we found the level of insulin and HOMA-IR were significantly higher in group 2 (insulin $5,39 \pm 3,93$ vs $8,94 \pm 6,15 \mathrm{mU} / \mathrm{L}, \mathrm{P}=0,006$; HOMA-IR $1,30 \pm 1,05$ vs $2,39 \pm 2,14, P=0,004$ ). This demonstrates the tendency to insulin resistance of tissues and can be a sign of a surgical stress response.

\section{CONCLUSION:}

Results of the study suggest that the limitation of intraoperative fluids does not affect haemodynamics but seems to increase the surgical stress response in children. Further research is necessary to determine which minimum volume is acceptable.

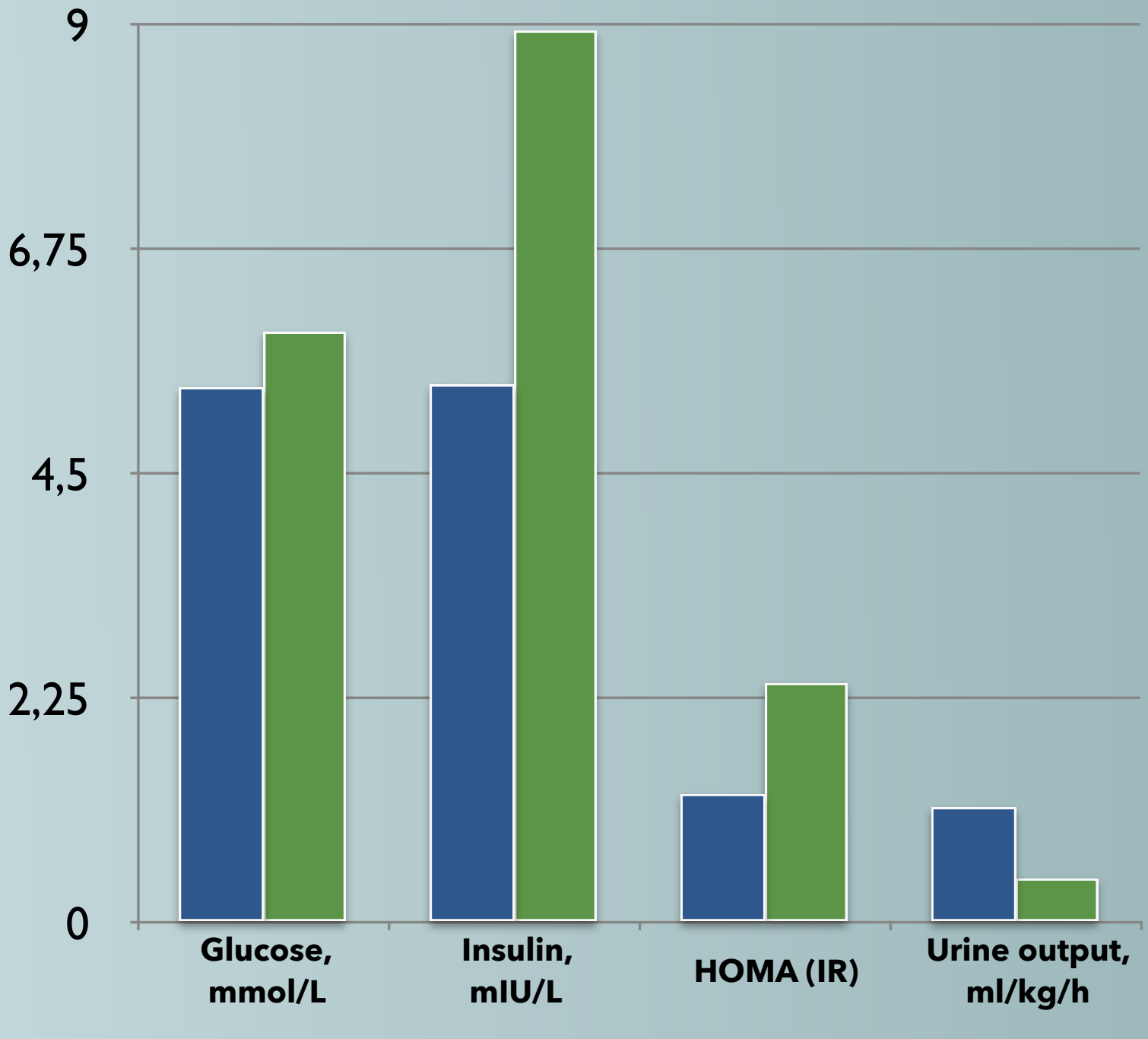

Levels of glucose, insulin, HOMA (IR) and Urine output after surgery

Group I 